\title{
MTHFD1L Gene
}

National Cancer Institute

\section{Source}

National Cancer Institute. MTHFD1L Gene. NCI Thesaurus. Code C92693.

This gene is involved in the regulation of folate metabolism. 